\title{
Analiza notranje strukture slovenske oblike Vprašalnika o sprejemanju bolečine (CPAQ)
}

\author{
Barbara Horvat $^{1 *}$, Helena Jamnik ${ }^{1}$, Gaj Vidmar ${ }^{1}$, Gregor Sočan² in Majda Mramor ${ }^{1}$ \\ ${ }^{1}$ Univerzitetni rehabilitacijski inštitut RS - Soča \\ ${ }^{2}$ Oddelek za psihologijo, Filozofska fakulteta, Univerza v Ljubljani
}

\begin{abstract}
Povzetek: V procesu sprejemanja kronične bolečine se omenja psihološki koncept sprejemanja, ki vključuje izpostavljenost bolečini, ki jo posameznik doživi brez poskusov izogibanja ali nadzora, ter vztrajanje v telesni aktivnosti navkljub prisotnosti bolečine. Na Univerzitetnem rehabilitacijskem inštitutu Republike Slovenije - Soča (URI - Soča) izvajamo program, v katerem celostno obravnavamo paciente s kronično razširjeno bolečino, kjer se prav tako soočamo s pomenom sprejemanja. Za merjenje koncepta sprejemanja uporabljamo Vprašalnik sprejemanja kronične bolečine (CPAQ, Chronic Pain Acceptance Questionnaire; McCracken idr., 2004), ki smo ga prevzeli iz angleško govorečega prostora. Namen naše študije je bil za ta instrument preveriti konstruktno veljavnost (prileganje dvofaktorskega modela - delitev 20 postavk v lestvici Pripravljenost na bolečino in Vključenost $\mathrm{v}$ aktivnost) ter zanesljivost $\mathrm{z}$ vidika notranje skladnosti in ponovnega merjenja. $\mathrm{V}$ študijo smo vključili 241 udeležencev, ki so bili med marcem 2011 in julijem 2013 pregledani v ambulanti za rehabilitacijo oseb s kronično nerakavo bolečino na URI - Soča. Vsi udeleženci so izpolnili CPAQ. Tako konfirmatorna faktorska analiza kot analiza postavk sta pokazali na neustreznost postavke 16, ki bi jo bilo v prihodnje smiselno opustiti ali preoblikovati. V splošnem se je zanesljivost $\mathrm{z}$ vidika notranje skladnosti (obeh lestvic in skupnega dosežka) in vidika ponovnega merjenja izkazala kot ustrezna predvsem za raziskovalne namene.
\end{abstract}

Ključne besede: kronična bolečina, spoprijemanje, vprašalniki, prevod, zanesljivost

\section{Construct validity and reliability of the slovenian version of the Chronic Pain Acceptance Questionnaire (CPAQ)}

\author{
Barbara Horvat $^{1 *}$, Helena Jamnik${ }^{1}$, Gaj Vidmar ${ }^{1}$, Gregor Sočan² and Majda Mramor ${ }^{1}$ \\ ${ }^{1}$ University Rehabilitation Institute - Soča, Ljubljana, Slovenia \\ ${ }^{2}$ Department of Psychology, Faculty of Arts, University of Ljubljana, Slovenia
}

\begin{abstract}
The psychological concept of acceptance has been increasingly considered in the process of chronic pain acceptance. The concept includes exposure to pain experienced without attempts of avoidance or control, and persistence in the physical activity in spite of chronic pain. At the University Rehabilitation Institute (URI) in Ljubljana, we are using the Slovenian version of the Chronic Pain Acceptance Questionnaire (CPAQ; McCracken et al., 2004) for measuring the concept of acceptance. The aim of our study was to investigate its construct validity (fit of the two-factor model, i.e., the division of the 20 items into the Pain Willingness and Activity Engagement scales) and its internal-consistency and retest reliability. The study included 241 participants who were examined at the outpatient clinic for patients with chronic non-malignant pain at the URI between March 2011 and June 2013. All of them completed the CPAQ. Confirmatory factor analysis and item analysis both pointed to inadequacy of the item No. 16, which should be either excluded or reworded. In general, reliability of the questionnaire (internal consistency of the two scales and of the total score, as well as retest reliability) proved to be adequate for research application.
\end{abstract}

Key words: chronic pain, coping behavior, questionnaires, translation, test reliability 
Kronična nerakava bolečina je večrazsežen pojav, saj vključuje tako čustvene komponente kot tudi komponente zaznavanja (McCracken, 1999; Hansen in Streltzer, 2005). V primerih, ko ne najdemo jasnih znakov okvar tkiv ali živčevja, s katerimi bi lahko pojasnili bolečino, jo uvrščamo v kategorijo funkcionalnih bolečinskih sindromov (Reneman, Dijkstra, Geertzen in Dijkstra, 2010). Zato je obravnava pacientov celostna in zajema tim strokovnjakov: zdravnika, fizioterapevta, delovnega terapevta, psihologa in socialnega delavca. Kot pravi Mramor (2013), poteka obravnava kronične bolečine skozi različna terapevtska okna. V članku se bomo oprli na okno, ki ga je odprl prehod v pojasnjevanju bolečine z biomedicinskega na biopsihosocialni model (Gatchel in Turk, 1996; Gatchel in Bell, 2000; Reneman idr., 2010). Usmerjen je v psihološke procese, ki sodelujejo pri doživljanju in vzdrževanju bolečine (Dahl, Wilson in Nilson, 2004; Reneman idr., 2010).

Aktualne teorije, ki se osredotočajo na odzive pacientov v povezavi s kronično bolečino in na prilagajanje nanjo, izpostavljajo psihološki koncept sprejemanja (angl. acceptance) (Dahl idr., 2004; McCracken, MacKichan in Eccleston, 2007; Reneman idr., 2010; Viane idr., 2003). Sprejemanje vključuje izpostavljenost bolečini, ki jo posameznik doživi brez poskusov izogibanja ali nadzora, ter vztrajanje $\mathrm{v}$ telesni aktivnosti navkljub prisotnosti bolečine (Bernini, Pennato, Cosci in Berrocal, 2010). Kot učinkovito se je izkazalo njegovo razlaganje prek kognitivno-vedenjskega modela, ki je v uporabi tudi pri nas (Jamnik, 2011; Jamnik, Mramor, Pirnat, Vidmar in Švajger, 2011; Mramor, 2013). Prek njega terapevti razložijo sovplivanje ter povezanost med mislimi, vedenjem in čustvovanjem. Rezultati študij kažejo, da je sprejemanje bolečine povezano z nižjo stopnjo poročanja o bolečini, z nižjim nivojem doživljanja stresa ter z učinkovitejšim in aktivnejšim vsakdanjim življenjem (McCracken, 1998; McCracken in Eccleston, 2003; McCracken, Spertus, Janeck, Sinclair in Wetzel, 1999; Stalnacke, 2011; Summers, Rapoff, Varghese, Porter in Palmer, 1991; Viane idr., 2003), hkrati pa učinkovito napoveduje stopnjo depresivnosti ter doživljanja anksioznosti.

Koncept sprejemanja bolečine je zato vse bolj vključen in upoštevan $\mathrm{v}$ terapevtsko rehabilitacijskih obravnavah (Costa in Pinto-Gouveia, 2011; McCracken, Vowles in Eccleston, 2004; Reneman idr., 2010). Tudi na Univerzitetnem rehabilitacijskem inštitutu Republike Slovenije - Soča (URI - Soča) skušamo med ocenjevalno triažnim pregledom $\mathrm{v}$ ambulanti za rehabilitacijo oseb $\mathrm{s}$ kronično nerakavo bolečino pridobiti podatke o stopnji sprejemanja kronične bolečine s pomočjo psihološkega razgovora in Vprašalnika o sprejemanju kronične bolečine (Chronic Pain Acceptance Questionnaire, CPAQ; McCracken idr., 2004). Prvotna oblika CPAQ je temeljila na vprašalniku čustvenega izogibanja (Hayes idr., 2003) in je vsebovala 34 vprašanj, na podlagi empiričnih ocen pa so jih 10 izključili. Preostale so merile štiri faktorje: (a) vključenost v vsakdanje aktivnosti, (b) prepričanje, da je možno prek nadzorovanja misli vplivati na doživljanje bolečine, (c) prepoznavanje kroničnosti bolečine in (d) potrebo po izogibanju ali nadzorovanju bolečine. Od leta 2004 je v uporabi vprašalnik z 20 postavkami, ki glede na faktorsko analizo odražajo dva metafaktorja (tvorijo dve podlestvici) - prvi je imenovan Vključenost v aktivnost (angl. Activity Engagement, AE) in združuje postavke, katerih vsebina je usmerjena na aktivno telesno udejstvovanje, ki ni odvisno od doživljanja bolečine; drugi pa Pripravljenost na bolečino (angl. Pain Willingness, PW), ki meri odsotnost poskusov izogibanja bolečini ali njenega nadzorovanja. Vsota vseh postavk daje skupno mero "sprejemanja" bolečine.

Vprašalnik CPAQ se širše uporablja tudi v Evropi (Bernini idr., 2010; Reneman idr., 2010; Rodero idr., 2010). Prevedli so ga v italijanščino (Bernini idr., 2010) in španščino (Rodero idr., 2010) ter izvedli analizo notranje strukture, kjer so podprli delitev postavk v zgoraj omenjeni podlestvici. Fish, McGuire, Hogan, Morrison in Stewart (2010) pa so s konfirmatorno faktorsko analizo podatkov, pridobljenih prek medmrežja na vzorcu 319 oseb s kronično bolečino, delitev postavk v dve podlestvici podprli zgolj ob izločitvi ene postavke, in sicer postavke 16.

Ker smo vprašalnik pred kratkim prenesli $\mathrm{v}$ naše jezikovno in kulturno okolje, smo želeli preveriti psihometrične značilnosti slovenske oblike CPAQ. Vprašalnik smo uporabili na vzorcu pacientov s kronično nerakavo bolečino. Na podlagi omenjenih predhodnih študij smo predpostavljali dvofaktorsko razvrstitev postavk in ustrezno notranjo zanesljivost vprašalnika.

\section{Metoda}

\section{Udeleženci}

V študijo smo vključili 241 oseb, ki so bile med marcem 2011 in julijem 2013 pregledane v ambulanti za rehabilitacijo oseb s kronično nerakavo bolečino na URISoča. Udeleženih je bilo 45 moških $(18,7 \%$ ) ter 196 žensk (81,3\%). Njihova povprečna starost je bila 47 let, stari so bili med 16 in 75 let.

\section{Pripomočki}

CPAQ je prosto dostopen samoocenjevalni vprašalnik stopnje sprejemanja kronične bolečine. Sestavljen je iz 20 postavk. Naloga udeležencev je, da vsako postavko ovrednotijo z ocenami od 0 (nikoli ne drži) do 6 (vselej drži). Postavke se glede na rezultate faktorske analize združujejo v dve lestvici - 9 postavk meri pripravljenost na bolečino (maksimalni rezultat je 54 točk; te postavke je potrebno vrednotiti obrnjeno), preostalih 11 postavk pa vključenost $v$ aktivnost (maksimalni rezultat je 66 točk). Pripravljenost na bolečino meri odsotnost poskusov, prek katerih bi skušali zmanjšati bolečino ali se ji izogniti, vključenost $\mathrm{v}$ aktivnost pa daje vpogled $\mathrm{v}$ pacientovo vpetost $\mathrm{v}$ vsakdanje aktivnosti in udejstvovanje ne glede 
na doživljanje bolečine. Skupni seštevek, ki daje vpogled v splošno tendenco po sprejemanju bolečine, lahko zavzame vrednosti med 0 in 120, pri čemer višji rezultat pomeni višjo stopnjo sprejemanja bolečine.

Predvideno točkovanje je:

- pripravljenost na bolečino (PW) - obrnemo vrednosti postavk $4,7,11,13,14,16,17,18$ in 20 ter jih seštejemo;

- vključenost $\mathrm{v}$ aktivnost (AE) - seštejemo vrednosti postavk: $1,2,3,5,6,8,9,10,12,15$ in 19 .

\section{Postopek}

Postopek prevajanja vprašalnika je bil opravljen na standarden način (strokovni prevod v slovenščino in nato nazaj v angleščino). Slovenski prevod CPAQ je v prilogi.

Podatke smo zbirali v okviru ambulantnih pregledov na URI - Soča, kjer so bili pacienti med ocenjevalnim triažnim pregledom deležni celostne obravnave s strani zdravnika specialista fizikalne in rehabilitacijske medicine in kliničnega psihologa. Pred pregledom so na dom prejeli sklop vprašalnikov tipa papir-svinčnik, ki so jih morali izpolniti $\mathrm{v}$ skladu $\mathrm{z}$ navodili in jih prinesti $\mathrm{s}$ seboj na obravnavo. Eden izmed teh vprašalnikov je bil tudi Vprašalnik sprejemanja kronične bolečine (CPAQ). Z namenom testiranja zanesljivosti pri ponovnem merjenju je prvih 62 pacientov ob pregledu izpolnilo še en izvod vprašalnika. Čas med prvim in ponovnim izpolnjevanjem vprašalnika ni presegel 14 dni.

Konfirmatorno(CFA) in eksploratorno(EFA) faktorsko analizo smo izvedli s programom Mplus 6.0 (Muthén in Muthén, 1998-2010). Za ocenjevanje parametrov smo uporabili metodo WLSMV, ki je privzeta za ordinalne opisne spremenljivke. Zanesljivost smo preverili z vidika klasične testne teorije. Izvedli smo analizo postavk in ocenili zanesljivost $\mathrm{z}$ metodo notranje skladnosti in $\mathrm{s}$ ponovnim testiranjem.

Manjkajoče vrednosti so se pojavljale pri $14 \%$ udeležencev, vendar je bil delež manjkajočih podatkov majhen - samo $1 \%$. Pri nobeni osebi ni manjkalo več kot 5 odgovorov. Pred klasično analizo postavk in zanesljivosti smo zato ocenili manjkajoče vrednosti z metodo EM v programu IBM SPSS Statistics 22. Eksploratorno in konfirmatorno faktorsko analizo smo izvedli na izvornih podatkih, torej brez zapolnjevanja manjkajočih vrednosti.

Vse statistične teste smo izvedli na stopnji značilnosti $\alpha=5 \%$. Pri konfirmatorni faktorski analizi smo za določanje ustreznosti prileganja modelov uporabili

Tabela 1. Faktorske uteži in komunalitete pri konfirmatorni faktorski analizi postavk CPAQ brez postavke 16

\begin{tabular}{|c|c|c|c|c|c|c|}
\hline lestvica & postavka & $\lambda$ & $S E(\lambda)$ & $t$ & $p$ & $h^{2}$ \\
\hline \multirow[t]{8}{*}{ PW } & 4 & 0,73 & 0,04 & 17,25 & $<0,001$ & 0,53 \\
\hline & 7 & 0,13 & 0,07 & 1,82 & 0,069 & 0,02 \\
\hline & 11 & 0,11 & 0,07 & 1,66 & 0,096 & 0,01 \\
\hline & 13 & 0,63 & 0,04 & 14,51 & $<0,001$ & 0,40 \\
\hline & 14 & 0,75 & 0,04 & 17,80 & $<0,001$ & 0,56 \\
\hline & 17 & 0,51 & 0,06 & 9,21 & $<0,001$ & 0,26 \\
\hline & 18 & 0,85 & 0,04 & 21,21 & $<0,001$ & 0,72 \\
\hline & 20 & 0,74 & 0,06 & 13,06 & $<0,001$ & 0,55 \\
\hline \multirow[t]{11}{*}{$\mathrm{AE}$} & 1 & 0,57 & 0,04 & 13,62 & $<0,001$ & 0,32 \\
\hline & 2 & 0,72 & 0,03 & 24,74 & $<0,001$ & 0,52 \\
\hline & 3 & 0,34 & 0,06 & 6,05 & $<0,001$ & 0,11 \\
\hline & 5 & 0,52 & 0,05 & 11,52 & $<0,001$ & 0,27 \\
\hline & 6 & 0,88 & 0,02 & 46,72 & $<0,001$ & 0,77 \\
\hline & 8 & 0,76 & 0,03 & 27,16 & $<0,001$ & 0,57 \\
\hline & 9 & 0,91 & 0,02 & 61,41 & $<0,001$ & 0,84 \\
\hline & 10 & 0,56 & 0,05 & 11,92 & $<0,001$ & 0,31 \\
\hline & 12 & 0,62 & 0,04 & 16,46 & $<0,001$ & 0,39 \\
\hline & 15 & 0,74 & 0,03 & 23,65 & $<0,001$ & 0,55 \\
\hline & 19 & 0,58 & 0,04 & 13,13 & $<0,001$ & 0,34 \\
\hline
\end{tabular}

Opomba. $\mathrm{PW}=$ Pripravljenost na bolečino, $\mathrm{AE}=$ Vključenost v aktivnost. $\lambda=$ standardizirana faktorska utež za ustrezni faktor, $S E=$ standardna napaka, $t=\lambda / S E(\lambda), p=$ vrednost $p$ za dvostranski test, $h^{2}=$ komunaliteta. 
naslednje kriterije: RMSEA $<0,06$, CFI $>0,95$, TLI $>0,95$ (Hu in Bentler, 1999), WRMR < 0,90 (Muthén, 19982004, str. 41-47), $p\left(\chi^{2}\right)>0,05, \chi^{2} / d f$ okoli 1 (Jöreskog, 1969).

\section{Rezultati}

Najprej smo s konfirmatorno faktorsko analizo preverili, ali tudi v slovenski različici vprašalnika CPAQ postavke odražajo dva faktorja tako kot $\mathrm{v}$ izvirniku (McCracken idr., 2004). Dvofaktorski model s predvideno razporeditvijo postavk se je sicer pokazal kot statistično značilno ustreznejši od enofaktorskega $\left(\chi^{2}=67,46 ; d f=1\right.$; $p<0,001)$, a je še vedno statistično značilno odstopal od podatkov $\left(\chi^{2}=684,96 ; d f=169 ; p<0,001\right)$. Tudi indeksi prileganja niso dosegli priporočenih vrednosti (RMSEA =0,113, 95 \% IZ [0,104-0,121]; CFI = 0,883; $\mathrm{TLI}=0,868 ; \mathrm{WRMR}=1,508$ ).

Na podlagi modifikacijskega indeksa, ki je za postavko 16 (ki je del Lestvice pripravljenosti na bolečino) znašal kar 132,19 (drugi največji je znašal 34,82 za postavko $7 \mathrm{z}$ iste lestvice), in na podlagi priporočil Fisha idr. (2010) smo nato izločili postavko 16 in ponovili konfirmatorno faktorsko analizo. Dvofaktorski model se je tudi brez postavke 16 pokazal kot izrazito ustreznejši od enofaktorskega $\left(\chi^{2}=86,17 ; d f=1 ; p<0,001\right)$. Model je sicer še vedno statistično značilno odstopal od podatkov $\left(\chi^{2}=489,75\right.$; $d f=151 ; p<0,001)$, a so bili indeksi prileganja ustreznejši: RMSEA = 0,096, $95 \%$ IZ [0,087-0,106]; CFI = 0,922; $\mathrm{TLI}=0,911$; WRMR $=1,293$ ). Rezultati so prikazani $\mathrm{v}$ tabeli 1. Vse uteži faktorja Vključenost $\mathrm{v}$ aktivnost so statistično značilne, vendar so zelo različnih višin; razpon komunalitet je od $11 \%$ do $84 \%$; povprečna komunaliteta je $45 \%$. Po drugi strani podlestvica Pripravljenost na bolečino še vedno vsebuje dve postavki (7 in 11), ki nimata statistično značilnih uteži pri ustreznem faktorju. Povprečna komunaliteta postavk te podlestvice je samo $38 \%$. Ocenjena korelacija med faktorjema je bila 0,58 $(p<0,001)$, kar kaže na precejšnjo stopnjo vsebinskega prekrivanja obeh latentnih konstruktov.

Zaradi nezadovoljivega prileganja modela smo izvedli tudi eksploratorno faktorsko analizo, da bi preverili, ali je slabo prileganje modela morda posledica neustrezne razporeditve postavk podlestvice in/ali neustreznega števila predpostavljenih faktorjev. Glede na rezultate preliminarne vzporedne analize po metodi glavnih osi, ki je nakazala pet statistično razločljivih faktorjev, smo primerjali rešitve $z$ enim do petimi faktorji. Prileganje dvofaktorske rešitve je bilo (zaradi prostih uteži) boljše v primerjavi s konfirmatorno analizo, vendar še vedno neustrezno: $\chi^{2}(134)=406,11, p<0,001$; RMSEA $=0,092$, $\mathrm{CFI}=0,937$; TLI $=0,920$. Tudi pri petfaktorski rešitvi prileganje še vedno ni bilo povsem zadovoljivo: $\chi^{2}(86)=199,61, p<0,001 ;$ RMSEA $=0,074, \mathrm{CFI}=0,974$; TLI $=0,948$.

Podrobnejši pregled s poševnokotno rotacijo Oblimin rotirane dvofaktorske rešitve (tabela 2) kaže, da imajo vse postavke višjo utež na predpostavljenem faktorju, čeprav imajo mnoge nezanemarljive uteži tudi na drugem faktorju. Prav tako so pri vseh postavkah faktorske uteži na predpostavljenem faktorju bistveno višje od standardne napake. Glede na to smo se odločili, da vseeno obdržimo teoretično predpostavljeno strukturo vprašalnika in nadaljujemo s klasično psihometrično analizo obeh vnaprej določenih podlestvic.

Ker postavke niso izrazito heterogene $\mathrm{z}$ vsebinskega ali formalnega vidika in zaradi zelo majhnega števila negativnih korelacij med postavkami, smo zanesljivost po metodi notranje skladnosti ocenili s koeficientom $\alpha$. Tabela 3 prikazuje rezultate klasične analize postavk in zanesljivosti za obe varianti lestvice pripravljenosti na bolečino, torej $\mathrm{z}$ in brez postavke 16. Aritmetične sredine odgovorov na postavke so bile razmeroma nizke: povprečna aritmetična sredina je bila 1,91 (na lestvici od 0 do 6). Povprečni popravljeni koeficient diskriminativnosti je bil 0,37 oz. 0,41, kar je načeloma zadovoljiva vrednost, vendar so imele postavke 7, 11 in 16 neustrezno nizko diskriminativnost - spodnja meja 95-odstotnega intervala zaupanja je bila pri njih pod 0,15 . Vrednosti koeficientov

Tabela 2. Faktorske uteži in komunalitete pri eksploratorni faktorski analizi postavk CPAQ brez postavke 16

\begin{tabular}{|c|c|c|c|c|c|}
\hline lestvica & postavka & $\lambda_{\mathrm{AE}}$ & $S E$ & $\lambda_{\mathrm{PW}}$ & $S E$ \\
\hline \multirow[t]{8}{*}{ PW } & 4 & 0,25 & 0,06 & 0,54 & 0,06 \\
\hline & 7 & $-0,26$ & 0,07 & 0,42 & 0,07 \\
\hline & 11 & $-0,06$ & 0,07 & 0,18 & 0,07 \\
\hline & 13 & $-0,04$ & 0,05 & 0,73 & 0,04 \\
\hline & 14 & 0,01 & 0,02 & 0,81 & 0,03 \\
\hline & 17 & $-0,02$ & 0,06 & 0,58 & 0,06 \\
\hline & 18 & 0,29 & 0,06 & 0,63 & 0,06 \\
\hline & 20 & 0,25 & 0,07 & 0,54 & 0,08 \\
\hline \multirow[t]{11}{*}{$\mathrm{AE}$} & 1 & 0,68 & 0,04 & $-0,20$ & 0,06 \\
\hline & 2 & 0,80 & 0,03 & $-0,12$ & 0,05 \\
\hline & 3 & 0,46 & 0,06 & $-0,20$ & 0,07 \\
\hline & 5 & 0,51 & 0,05 & 0,02 & 0,07 \\
\hline & 6 & 0,85 & 0,03 & 0,06 & 0,05 \\
\hline & 8 & 0,69 & 0,04 & 0,14 & 0,06 \\
\hline & 9 & 0,93 & 0,01 & 0,00 & 0,01 \\
\hline & 10 & 0,46 & 0,06 & 0,17 & 0,07 \\
\hline & 12 & 0,63 & 0,05 & $-0,01$ & 0,05 \\
\hline & 15 & 0,61 & 0,05 & 0,24 & 0,06 \\
\hline & 19 & 0,47 & 0,06 & 0,19 & 0,07 \\
\hline
\end{tabular}

Opomba. $\mathrm{PW}=$ Pripravljenost na bolečino, $\mathrm{AE}=$ Vključenost $\mathrm{v}$ aktivnost. $\lambda=$ standardizirana faktorska utež, $S E=$ standardna napaka. 
Tabela 3. Analiza postavk za lestvico Pripravljenost na bolečino

\begin{tabular}{|c|c|c|c|c|c|c|c|c|}
\hline \multirow[b]{2}{*}{ postavka } & \multirow[b]{2}{*}{$M$} & \multirow[b]{2}{*}{$S D$} & \multicolumn{3}{|c|}{ s postavko 16} & \multicolumn{3}{|c|}{ brez postavke 16} \\
\hline & & & $r_{\mathrm{iSc}}$ & $\mathrm{IZ}_{\mathrm{sp}}$ & $\alpha^{-}$ & $r_{\mathrm{iSc}}$ & $\mathrm{IZ}_{\mathrm{sp}}$ & $\alpha^{-}$ \\
\hline 4 & 1,71 & 1,94 & 0,36 & 0,27 & 0,66 & 0,44 & 0,35 & 0,68 \\
\hline 7 & 1,96 & 1,93 & 0,25 & 0,14 & 0,68 & 0,20 & 0,09 & 0,73 \\
\hline 11 & 3,02 & 2,01 & 0,22 & 0,11 & 0,69 & 0,16 & 0,06 & 0,74 \\
\hline 13 & 2,24 & 1,89 & 0,50 & 0,41 & 0,63 & 0,51 & 0,43 & 0,66 \\
\hline 14 & 1,95 & 1,96 & 0,63 & 0,56 & 0,60 & 0,66 & 0,60 & 0,62 \\
\hline 16 & 2,77 & 2,31 & 0,14 & 0,04 & 0,71 & / & l & / \\
\hline 17 & 1,23 & 1,66 & 0,42 & 0,33 & 0,65 & 0,41 & 0,31 & 0,69 \\
\hline 18 & 1,24 & 1,71 & 0,44 & 0,35 & 0,64 & 0,51 & 0,43 & 0,66 \\
\hline 20 & 1,03 & 1,66 & 0,39 & 0,30 & 0,65 & 0,41 & 0,32 & 0,68 \\
\hline$M$ & 1,91 & 1,90 & 0,37 & & & 0,41 & & \\
\hline$\alpha[\mathrm{IZ}]$ & & & \multicolumn{3}{|c|}{$0,69[0,63]$} & \multicolumn{3}{|c|}{$0,71[0,67]$} \\
\hline
\end{tabular}

Opomba $. \mathrm{IZ}_{\mathrm{sp}}=$ spodnja meja 95-odstotnega intervala zaupanja. $r_{\mathrm{isc}}=$ korelacija med postavko in lestvico brez nje, $\alpha^{-}=\alpha$ brez postavke.

“ $\alpha$ brez postavke" kažejo, da bi bilo z vidika zanesljivosti smiselno izločiti vse tri postavke.

Rezultate za lestvico vključenosti v aktivnosti prikazuje tabela 4. Pri postavkah te lestvice so udeleženci v povprečju dajali višje ocene $(M=2,60)$, razpršenost odgovorov pa je bila v povprečju podobna kot pri postavkah lestvice pripravljenosti na bolečino. Diskriminativnost postavk je bila ustreznejša v primerjavi s prvo podlestvico: vsi koeficienti diskriminativnosti so bili višji od 0,30 , za nobeno postavko pa ne velja, da bi njena izločitev izboljšala koeficient $\alpha$, ki je za to lestvico znašal 0,87 .

$\mathrm{S}$ pomočjo obrazca za zanesljivost sestavljenega dosežka (gl. npr. Sočan, 2004, str. 45) smo ocenili tudi zanesljivost skupnega dosežka. Če skupni dosežek računamo kot vsoto odgovorov na vse postavke (oz. vsoto surovih dosežkov na obeh podlestvicah), je njegova zanesljivost 0,84 (oz. 0,87 brez postavke 16), če pa bi ga računali kot vsoto standardiziranih dosežkov na obeh

Tabela 4. Analiza postavk za lestvico Vključenost $v$ aktivnost

\begin{tabular}{lccccc}
\hline postavka & $M$ & $S D$ & $r_{\text {isc }}$ & $\mathrm{IZ}_{\mathrm{sp}}$ & $\alpha^{-}$ \\
\hline 1 & 3,78 & 1,78 & 0,51 & 0,42 & 0,86 \\
2 & 3,16 & 1,80 & 0,66 & 0,59 & 0,85 \\
3 & 3,14 & 2,22 & 0,33 & 0,23 & 0,87 \\
5 & 2,84 & 1,82 & 0,46 & 0,37 & 0,86 \\
6 & 2,44 & 1,90 & 0,76 & 0,71 & 0,84 \\
8 & 2,63 & 1,85 & 0,65 & 0,58 & 0,85 \\
9 & 2,32 & 1,95 & 0,80 & 0,75 & 0,84 \\
10 & 2,52 & 1,91 & 0,48 & 0,39 & 0,86 \\
12 & 3,75 & 1,96 & 0,55 & 0,47 & 0,85 \\
15 & 2,03 & 1,88 & 0,60 & 0,53 & 0,85 \\
19 & 1,74 & 1,85 & 0,45 & 0,36 & 0,86 \\
\hline$M$ & 2,60 & 1,93 & 0,56 & & \\
$\alpha[\mathrm{IZ}]$ & & & & \multicolumn{2}{c}{$0,87[0,84]$} \\
\hline
\end{tabular}

Opomba $. \mathrm{IZ}_{\mathrm{sp}}=$ spodnja meja 95-odstotnega intervala zaupanja. $r_{\text {isc }}=$ korelacija med postavko in lestvico brez nje, $\alpha^{-}=\alpha$ brez postavke. podlestvicah, bi bila zanesljivost 0,82 (oz. 0,84 brez postavke 16). Vsota standardiziranih dosežkov ima nižjo zanesljivost, ker so imeli dosežki na lestvici Pripravljenost na bolečino hkrati večjo razpršenost in višjo zanesljivost (prim. tabele 3-5).

Za 62 posameznikov, ki so vprašalnik izpolnili dva meseca po zaključku rehabilitacije, je Pearsonov koeficient korelacije med skupnima dosežkoma (tj. ocenjena retestna zanesljivost skupnega dosežka) znašal 0,789, s 95-odstotnim intervalom zaupanja [0,672;0,867].

Medsebojna korelacija lestvic PW in AE je znašala 0,22 (oziroma 0,35 brez upoštevanja postavke 16; obakrat je bil $p<0,001)$. Pregled razsevnega diagrama z LOWESS črto kaže, da je povezanost praktično linearna.

Tabela 5 prikazuje opisne statistike za obe podlestvici ter za vsoto vseh postavk. Podlestvica Vključenost v aktivnost ima precej večjo razpršenost od podlestvice Pripravljenost na bolečino, kar pomeni, da tudi v večji meri določa skupni dosežek na lestvici. Koeficienti asimetrije in sploščenosti (kot tudi normalni kvantilni grafi, ki niso prikazani) kažejo na blago odstopanje od normalne porazdelitve.

\section{Razprava}

Obravnava pacientov s kronično nerakavo bolečino v Ambulantno rehabilitacijski službi URI - Soča je celostna in vključuje tudi psihološko obravnavo. Ker aktualne teorije, ki se osredotočajo na odzive pacientov $\mathrm{V}$ povezavi s kronično bolečino in na prilagajanje nanjo (Dahl idr., 2004;McCracken idr., 2007; Reneman idr., 2010), izpostavljajo psihološki koncept sprejemanja, smo nanj pozorni tudi v našem programu. Poleg začetnega psihološkega razgovora skušamo podatke o stopnji sprejemanja bolečine pridobiti tudi z uporabo Vprašalnika o sprejemanju bolečine (CPAQ). Instrument je bil od svojega nastanka v letu 1992 na podlagi psihometričnih značilnosti že večkrat preoblikovan. Najsodobnejša 
Tabela 5. Opisne statistike lestvic CPAQ

\begin{tabular}{lrrrrrrrrr}
\hline & $M$ & $S D$ & Min & Max & $Q 1$ & $M d n$ & $Q 3$ & Asim. & Spl. \\
\hline Skupaj & 47,5 & 18,16 & 6 & 97 & 33 & 47 & 60 & 0,21 & $-0,39$ \\
AE & 30,3 & 13,68 & 1 & 63 & 19 & 30 & 40 & 0,13 & $-0,72$ \\
PW & 17,2 & 9,16 & 0 & 51 & 12 & 16 & 23 & 0,55 & 0,43 \\
PW- & 14,4 & 8,54 & 0 & 46 & 8 & 13 & 20 & 0,63 & 0,22 \\
\hline
\end{tabular}

Opomba. Skupaj = AE + PW; AE = Vključenost v aktivnost, PW = Pripravljenost na bolečino, PW- = Pripravljenost na bolečino brez postavke 16. Q1, Q3 = prvi in tretji kvartil. Asim. = koeficient asimetričnosti. Spl. = koeficient sploščenosti.

različica (McCracken idr., 2004) je skrajšana na 20 postavk. To obliko vprašalnika smo nedavno prevedli in začeli uporabljati pri delu s pacienti s kronično bolečino. Tuje študije (Costa in Pinto-Gouveia, 2011; McCracken idr., 2007) so pokazale ustrezno konstruktno veljavnost in zanesljivost vprašalnika, mi pa smo želeli preveriti osnovne psihometrične značilnosti slovenske oblike CPAQ.

Najprej smo s konfirmatorno faktorsko analizo preverili prileganje naših podatkov predpostavljenemu modelu. Mere prileganja dvofaktorskega modela, ki ga podpirajo tuje študije (Bernini idr., 2010; McCracken idr., 2004; Reneman idr., 2010; Rodero idr., 2010), so bile blizu pogojno zadovoljivim vrednostim, pri čemer je potrebno postavko 16 izločiti iz lestvice. Do enakega sklepa glede te postavke so prišli tudi Fish idr. (2010). Tudi analiza zanesljivosti z vidika notranje skladnosti kaže, da je lestvica Pripravljenost na bolečino ustreznejša brez postavke 16. Vse opravljene analize so poleg postavke 16 kot manj ustrezni izpostavile tudi postavki 7 in $11 \mathrm{z}$ iste lestvice (kar je skladno $\mathrm{z}$ nižjo notranjo skladnostjo te lestvice).

Postavke 7, 11 in 16 (gl. prilogo) je zato smiselno analizirati tudi z vsebinskega vidika. Postavka 7 najbrž izstopa zaradi izražanja prisile ("moram"), ki v drugih postavkah ni tako neposredna. Pri postavkah 11 in 16 pa je vsebina podana v obliki pogojnika oziroma spremembe v prihodnosti. Tovrstne postavke lahko delujejo neosebno, zaradi česar se nekateri udeleženci z njimi morda ne uspejo dovolj poistovetiti. Za primerjavo lahko služita postavki 6 in 9, ki imata najboljše merske lastnosti (najvišjo diskriminativnost idr.) in sta mnogo bolj neposredni (6 - "Čeprav so se stvari zaradi bolečin spremenile, lahko tudi z bolečinami živim normalno življenje" in 9 - "Kljub stalnim bolečinam živim polno življenje"). Poleg izločitve postavke 16 bi bilo pred dokončno uvedbo v klinično prakso torej priporočljivo tudi preoblikovati postavki 7 in 11 na način, da bi prva izražala manj neposredne prisile, druga pa bi bila bolj osebno usmerjena. Seveda bi bilo $\mathrm{v}$ tem primeru priporočljivo ponovno preveriti merske lastnosti vprašalnika.

Vzorec faktorskih uteži v dvofaktorski eksploratorni rešitvi kaže, da je razloge za slabo prileganje treba iskati predvsem $\mathrm{v}$ faktorski kompleksnosti postavk in ne $\mathrm{v}$ neustrezni razporeditvi postavk v podlestvice. Za dobro pojasnjevanje korelacij med postavkami bi torej morali privzeti relativno veliko število latentnih konstruktov, od katerih bi bili nekateri vsebinsko težko interpretabilni in statistično nestabilni. Seveda bi bilo oblikovanje petih (ali več) podlestvic iz 20 postavk tudi s psihometričnega vidika nesprejemljivo, saj bi imele takšne lestvice zelo nizko zanesljivost. Faktorska kompleksnost na ravni postavk oz. slabo prileganje modelov $\mathrm{z}$ majhnim številom faktorjev je sicer problem, ki se pogosto pojavlja pri analizi osebnostnih vprašalnikov in po mnenju mnogih raziskovalcev kaže, da so uveljavljeni kriteriji presojanja prileganja modelov prestrogi za ta tip podatkov (gl. npr. Church in Burke, 1994; Muthén in Asparouhov, 2012).

Temeljni doprinos naše študije vidimo $\mathrm{v}$ dopolnitvi nabora psihodiagnostičnih sredstev $\mathrm{v}$ klinični praksi. Vprašalnik CPAQ bi lahko bil psihologom potencialno $\mathrm{v}$ pomoč pri identifikaciji stopnje sprejemanja bolečine ter pri nadaljnjem načrtovanju programa rehabilitacije. Na sedanji stopnji razvoja in pri izbrani ciljni skupini (torej bolnikih s kronično bolečino) je instrument glede na zanesljivost podlestvic primeren predvsem za raziskovalne namene (prim. Nunnally in Bernstein, 1994, str. 264) ali kot sestavni del širše diagnostične baterije.

$\mathrm{V}$ nadaljevanju nameravamo CPAQ revidirati, predvsem $\mathrm{z}$ izločitvijo postavke 16 in s preoblikovanjem postavk 7 in 11, potencialno pa tudi nekaterih drugih postavk, ki imajo - glede na rezultate eksploratorne faktorske analize - nezanemarljive uteži na obeh faktorjih (npr. 4, 7, 18 in 20). V prihodnje bomo poskušali razviti tudi norme ter preveriti kriterijsko veljavnost in zunanje vidike konstruktne veljavnosti vprašalnika, s čimer bo CPAQ postal uporabno orodje tudi za individualno klinično diagnostiko pacientovega soočanja z bolečino.

\section{Literatura}

Bernini, O., Pennato, T., Cosci, F. in Berrocal, C. (2010). The psychometric properties of the Chronic Pain Acceptance Questionnaire in Italian patients with chronic pain. Journal of Health Psychology, 15(8), 1236-1245.

Church, A. T. in Burke, P. J. (1994). Exploratory and confirmatory tests of the Big Five and Tellegen's three- and four-dimensional models. Journal of Personality and Social Psychology, 66, 93-114.

Costa, J. in Pinto-Gouveia, J. (2011). Acceptance of pain, self-compassion and psychopathology: Using the Chronic Pain Acceptance Questionnaire to identify 
patients' subgroups. Clinical Psychology and Psychotherapy, 18, 292-302.

Fish, R. A., McGuire, B., Hogan, M., Morrison, T. G. in Stewart, I. (2010). Validation of the Chronic Pain Acceptance Questionnaire (CPAQ) in an internet sample and development and preliminary validation of the CPAQ-8. Pain, 149(3), 435-443.

Dahl, J. C., Wilson, K. G. in Nilson, A. (2004). Acceptance and commitment therapy and the treatment of persons at risk for long-term disability resulting from stress and pain symptoms: a preliminary randomized trial. Behaviour Therapy, 35, 785-801.

Gatchel, R. J. in Turk, D. C. (1996). Psychological Approaches to Pain Management: A Practitioner's Handbook. New York: Guilford Publications.

Gatchel, R. J. in Bell, G. (2000). The biopsychosocial approach to spine care and research. Spine, 25(20), 2572 .

Hansen, G. R. in Streltzer, J. (2005). The psychology of pain. Emergency Medicine Clinics of North America, 23, 339-348.

Hayes, S. C., Strosahl, K. D., Wilson, K. G., Bissett, R. T., Pistorello, J., Toermino, D., ... McCurry, S. M. (2003). Measuring experiental avoidance: a preliminary test of a working model. The Psychological Record, 54, 553-578.

Hu, L. T. in Bentler, P. M. (1999). Cutoff criteria for fit indexes in covariance structure analysis: Conventional criteria versus new alternatives. Structural Equation Modeling, 6, 1-55.

Jamnik, H. (2011). Kronična razširjena bolečina. V: M. Kamenik, N. Krčevski-Škvarč in S. Lahajnar (ur.), Zbornik: Vpliv bolečine na družbo (str. 115-116), Ljubljana: Univerzitetni rehabilitacijski inštitut Republike Slovenije - Soča.

Jamnik, H., Mramor, M., Pirnat, B., Vidmar, J. in Švajger, A. (2011). Interdisciplinarna rehabilitacija oseb $\mathrm{s}$ kronično bolečino. V: M. Kamenik, N. KrčevskiŠkvarč in S. Lahajnar (ur.), Zbornik: Vpliv bolečine na družbo, Ljubljana: Univerzitetni rehabilitacijski inštitut Republike Slovenije - Soča, 117-120.

Jöreskog, K. G. (1969). A general approach to confirmatory factor analysis. Psychometrika, 34, 183-202.

McCracken, L. M. (1998). Acceptance of pain predicts adjustment in persons with chronic pain. Pain, 74, 21-27.

McCracken, L. M. (1999). Behavioral constituents of chronic pain acceptance: Results from factor analysis of the Chronic Pain Acceptance Questionnaire. Journal of Back and Musculoskeletal Rehabilitation, 13, 93-100.

McCracken, L. M., Spertus, I. L., Janeck, A. S., Sinclair, D. in Wetzel, F. T. (1999). Behavioral dimensions of adjustment in persons with chronic pain: pain related anxiety and acceptance. Pain, 80, 283-289.

McCracken, L. M. in Eccleston, C. (2003). Coping or acceptance: what to do about chronic pain? Pain, 105, 197-204.
McCracken, L. M., Vowles, K. E. in Eccleston, C. (2004). Acceptance of chronic pain: component analysis and a revised assesment method. Pain, 107, 159-166.

McCracken, L. M., MacKichan, F. in Eccleston, C. (2007). Contextual cognitive-behavioral therapy for severely disabled chronic pain sufferers: effectiveness and clinically significant shange. European Journal of Pain, 11, 314-322.

Mramor, M. (2013). Uporaba psihosocialnih metod v obravnavi oseb s kronično nerakavo bolečino. V: D. Marn-Vukadinović, M. Štefančič, H. Burger, N. Goljar in M. Moharić (ur.), Kronična nerakava bolečina $v$ vratu : učbenik za zdravnike in zdravstvene delavce (str. 64-69). Ljubljana: URI-Soča.

Muthén, B. O. (1998-2004). Mplus Technical Appendices. Los Angeles, CA: Muthén \& Muthén.

Muthén, B. in Asparouhov, T. (2012). Bayesian structural equation modeling: A more flexible representation of substantive theory. Psychological Methods, 17, 313-335.

Muthén, L. K. in Muthén, B. O. (1998-2010). Mplus User's Guide (6. izd.). Los Angeles, CA: Muthén \& Muthén.

Nunnally, J. in Bernstein, I. (1994). Psychometric Theory (3. izd.). New York, NY: McGraw-Hill.

Reneman, M. F., Dijkstra, A., Geertzen, J. H. B. in Dijkstra, P. U. (2010). Psychometric properties of Chronic Pain Acceptance Questionnaires: A systematic review. European Journal of Pain, 14, 457-465.

Rodero, B., Garcia-Campayo, J., Casanueva, B., Lopez del Hoyo, J., Serrano-Blanco, A. in Luciano, J. V. (2010). Validation of the Spanish version of the Chronic Pain Acceptance Questionnaire (CPAQ) for the assessment of acceptance in fibromyalgija. Health and Quality of Life Outcomes, 8(37), 1-10.

Sočan, G. (2004). Postopki klasične testne teorije. Ljubljana: Filozofska fakulteta.

Stalnacke, B. M. (2011). Life satisfaction in patients with chronic pain - relation to pain intensity, disability, and psychological factors. Neuropsychiatric Disease and Treatment, 7, 683-689.

Summers, J. D., Rapoff, M. A., Varghese, G., Porter, K. in Palmer, R. E. (1991). Psychosocial factors in chronic spinal cord injury pain. Pain, 58, 280-282.

Viane, I., Cromber, G., Eccleston, C., Poppe, C., Devulder, J., Van Houdenhove, B. in De Corte, W. (2003). Acceptance of pain is an independent predictor of mental well-being in patients with chronic pain: Empirical evidence and reappraisal. Pain, 106, 65-72. 
Priloga: Uporabljeni slovenski prevod

Vprašalnika o sprejemanju bolečine (CPAQ)

1. Vztrajam pri opravljanju vseh aktivnosti zasebno in $\mathrm{v}$ poklicnem življenju, ne glede na jakost bolečine.

2. V življenju mi gre dobro, čeprav imam stalne bolečine.

3. Doživljanje bolečine je nekaj običajnega.

4. Takoj bi žrtvoval(a) pomembne stvari v svojem življenju, če bi to ublažilo moje bolečine.

5. Ni potrebno povsem obvladovati bolečin, če želiš živeti polno življenje.

6. Čeprav so se stvari zaradi bolečin spremenile, lahko tudi z bolečinami živim normalno življenje.

7. Moram se osredotočiti na to, da se znebim bolečin.

8. Tudi ko občutim bolečine, lahko marsikaj počnem.

9. Kljub stalnim bolečinam živim polno življenje.

10. Ukvarjanje $\mathrm{z}$ obvladovanjem bolečine je zame manj pomembno kot izpolnjevanje drugih ciljev, ki si jih zastavim.

11. Preden se bom lotil(a) pomembnih življenjskih korakov, moram spremeniti svoja prepričanja in občutja $\mathrm{v}$ zvezi $\mathrm{z}$ bolečino.

12. Kljub bolečinam se sedaj držim smeri v življenju, ki sem si jo izbral(a).

13. Pri vsaki dejavnosti je zame na prvem mestu obvladovanje jakosti bolečine.

14. Preden se bom lotil(a) resnejših načrtov, moram svoje bolečine ukrotiti.

15. Svoje obveznosti lahko izpolnjujem tudi takrat, ko občutim močnejše bolečine.

16. Če bom nadziral(a) slabe misli, povezane $\mathrm{z}$ bolečino, se bom v življenju bolje znašel(la).

17. Izogibam se položajem, v katerih bi se mi bolečine lahko ojačile.

18. Zaradi posledic bolečine sem upravičeno zaskrbljen(a).

19. Z olajšanjem ugotavljam, da mi ni potrebno spreminjati bolečin, da bi lahko živel(a) dalje.

20. Ko se bolečine ojačijo, počnem vse z veliko muko. 